\title{
PEMBELAJARAN MENDESAIN RUMAH MENGGUNAKAN MEDIA AUDIO VISUAL DENGAN MEMANFAATKAN BANDICAM
}

\author{
Lovy Herayanti, Baiq Rina Amalia Safitri \\ Program Studi Pendidikan Fisika, Universitas Pendidikan Mandalika \\ *Email : lovyherayanti@ikipmataram.ac.id
}

DOI: http://dx.doi.org/10.29303/jpft.v5i2.1429

\begin{abstract}
$\overline{\text { Abstract } \text { - This research is motivated by the fact that teachers in learning have never used instructional }}$ media in the form of audio-visual or video in explaining learning materials for home design. This research is a development research (development research) with 4D design (define, design, developed, desimination). The study was conducted in the department of building engineering at SMKN 2 Kuripan especially on home design subjects. Retrieval of research data using project-based classical completeness tests. The results of the study, as many as $82.61 \%$ or 19 students thoroughly designed the house without having to do remidial, while the remaining $17.39 \%$ or 4 new people declared complete after remidial. In the second stage, students are assigned to practice the material by designing house plans. $100 \%$ complete results. Based on classical completeness data, bandicam-based audio visual media is proven to be able to provide effective learning.
\end{abstract}

Keywords: media audio visual; bandicam; home design

\section{PENDAHULUAN}

Rini \& Tari (2013) menyatakan bahwa pendidikan adalah segala daya upaya dan semua usahauntuk membuat masyarakat dapat mengembangkan potensi manusia agar memiliki kekuatan spiritual keagamaan, pengendalian diri, berkepribadian, memiliki kecerdasan, berakhlak mulia, serta memiliki keterampilan yang diperlukan sebagai anggota masyarakat dan warga negara. Di samping itu pendidikan merupakan usaha untuk membentuk manusia yang utuh lahir dan batin cerdas, sehat, dan berbudi pekerti luhur. Agar memperoleh kehidupan yang bahagia dan apa yang dilakukan dapat bermanfaat bagi dirinya sendiri, masyarakat, bangsa, negara dan agamanya.

Undang-undang No. 2 Tahun 1989, pendidikan kejuruan telah masuk dalam Sistem Pendidikan Nasional secara hukum, yaitu jenis pendidikan yang termasuk dalam jalur pendidikan sekolah (Pasal 11, Ayat 1). Selanjutnya, dalam Pasal 11 Ayat 3 disebutkan, "pendidikan kejuruan merupakan pendidikan yang mempersiapkan peserta didik untuk dapat bekerja dalam bidang tertentu". Namun, karena rumusannya terlalu singkat dan pada porsi yang kecil, kedudukan pendidikan kejuruan tersebut masih belum kuat dan belum jelas. Sebagai komparasi, di Amerika Serikat kebijakan pendidikan kejuruan telah lama dirumuskan secara rinci dalam sebuah undang-undang tersendiri, yaitu Vocational Education Aci of 1963, yang kemudian diamandemen tahun 1968 dan 1976 (Calhoun \& Finch, 1982).

Undang-undang No. 29 Tahun 1990 pada Pasal 1 menjelaskan bahwa Pendidikan Menengah Kejuruan (SMK) adalah pendidikan pada jenjang pendidikan menengah yang mengutamakan pengembangan kemampuan siswa untuk melaksanakan jenis pekerjaan tertentu. Pada Pasal 3 menjelaskan pendidikan menengah kejuruan mengutamkan penyiapan siswa untuk memasuki lapangan kerja serta mengembangkan sikap profesional. Pada Pasal 7 menjelaskan pendirian sekolah menengah kejuruan harus memenuhi persyaratan tersedianya potensi lapangan kerja dan dukungan masyarakat, termasuk dunia usaha/industri. 
Pada umumnya pembelajaran mendesain rumah pada program studi kontruksi bangunan di SMK sering mengalami kendala, seperti kurang memiliki keterampilan mendesain rumah karena masih menggunakan pembelajaran konvensional dan tidak menggunakan media pembelajaran. Fasilitas multimedia dapat membuat belajar lebih menarik, visual dan interaktif. Hamalik dalam (Arsyad, 2011) menyatakan bahwa pemakaian media pembelajaran dalam proses pembelajaran dapat membangkitkan motivasi dan rangsangan kegiatan belajar, dan bahkan membawa pengaruh-pengaruh psikologi terhadap siswa.

Berdasarkan hasil observasi bulan Maret 2019 secara langsung dan wawancara dengan guru program studi kontruksi bangunan di SMKN 2 Kuripan ditemukan beberapa fenomena, antara lain: (1) pada saat proses pembelajaran berlangsung, guru masih mendominasi kelas, (2) siswa cenderung pasif, hanya mencatat apa yang disampaikan guru tanpa ada respon balik terhadap apa yang dicatat atau disampaikan, (3) guru dalam pembelajaran belum pernah menggunakan media pembelajaran dalam bentuk audio visual atau video dalam menjelaskan materi pembelajaran mendesain rumah dan mampu memanfaatkan perangkat lunak microsoft word.

Pembelajaran yang hanya dilakukan monoton terus-menerus dari tahun ke tahun yang bertempat di laboraturium atau di dalam kelas saja, membuat proses pembelajaran menjadi membosankan sehingga kosentrasi dalam menerima pelajaran menjadi berkurang. Diharapkan dengan proses pembelajaran menggunakan video atau audio visual yaitu memanfaatkan perkembangan teknologi (komputer, internet, dan perangkat lunak) dalam upaya meningkatkan keterampilan mendesain rumah, selain itu juga menciptakan belajar yang menarik dan menyenangkan.

Keberhasilan dari siswa SMKN 2 Kuripan untuk dapat meningkatkan keterampilan yaitu salah satunya dengan pemilihan model pembelajaran yang tepat oleh seorang guru. Menurut Walter Dick dan Lou Carey (2005) dalam (Pribadi, 2009) mendefinisikan pembelajaran sebagai rangkaian peristiwa atau kegiatan yang disampaikan secara terstruktur dan terencana dengan menggunakan sebuah atau beberapa jenis media. Proses pembelajaran mempunyai tujuan agar siswa dapat mencapai kompetensi seperti yang diharapkan. Untuk mencapai tujuan tersebut proses pembelajaran perlu dirancang secara sistematik dan sistemik. Proses merancang aktivitas pembelajaran disebut dengan istilah desain sistem pembelajaran.

Salah satu upaya peningkatan keterampilan pada saat ini adalah dengan pengembangan media pembelajaran berbasis teknologi informasi komunikasi (TIK) misalnya dengan menggunakan media video dalam penyajian materi pembelajaran. Media video atau audiovisual adalah media yang mempunyai unsur suara dan unsur gambar. Jenis media ini mempunyai kemampuan yang lebih baik, karena meliputi kedua jenis media yang pertama dan kedua (Djamarah \& Zain, 2006).

Teknologi video memberi keuntungan optimal jika digunakan sesuai dengan potensi yang dikandungnya. Media video memberi kesempatan kepada penggunanya untuk belajar melalui unsur suara (audio) dan gambar (visual) secara simultan. Media ini dapat digunakan untuk menyampaikan informasi dan pengetahuan secara realistik dan konkret, yang tidak mungkin disampaikan oleh media cetak (Pribadi, 2009).

Untuk mengatasi permasalahan di atas, maka perlu dilakukan perubahan dalam 
proses pembelajaran agar dapat meningkatkan keterampilan siswa.

\section{METODE PENELITIAN}

Penelitian yang akan dilakukan ini diklasifikasikan ke dalam penelitian pengembangan (development research) 4D (define, design, developed, desiminasi)

Penelitian ini akan melewati beberapa tahapan, antara lain:

1. Tahap persiapan (Pencarian Informasi)

2. Tahap pelaksanaan, terbagi menjadi 4 tahapan, yaitu:

a. Analisis silabus mata pelajaran gambar bangunan dan penyusunan video pembelajaran desain rumah dengan memanfaatkan aplikasi bandicam.

Pada tahapan ini, penelitian akan difokuskan pada kajian silabus untuk bahan penyusunan silabus dan video pembelajaran desain rumah dalam bentuk Microsoft word dengan memanfaatkan aplikasi bandicam pada siswa jurusan bangunan. Materi-materi yang digunakan sebagai bahan video adalah berasal dari buku-buku referensi yang sudah ada. Diharapkan, setelah terbentuknya video pembelajaran desain rumah dengan memanfaatkan aplikasi bandicam, maka siswa mampu memanfaatkan mendesain rumah.

b. Uji validitas video pembelajaran desain rumah dalam bentuk Microsoft word dengan memanfaatkan aplikasi bandicam.

Pada tahapan ini, uji validitas dilakukan oleh dua dosen yang ahli pada bidang pendidikan.

3. Uji coba

Pada tahap ini media diujicobakan secara terbatas pada pembelajaran. Desain penelitian yang digunakan pada tahap ujicoba adalah one shot case study dengan pre-post test design. Sample penelitian ini adalah kelas X salah satu sekolah kejuruan di mataram.

4. Analisis hasil
Data efektifitas hasil belajar siswa dianalisis menggunakan uji ketuntasan klasikal. Data yang didapatkan berupa data peningkatan hasil belajar siswa yang menerapkan media.

\section{HASIL DAN PEMBAHASAN}

Berdasarkan pada hasil tes siswa pada tahap pertama, setelah siswa ditugaskan mempraktekkan membaca dan memahami materi yang telah ditampilkan melalui video, sebanyak $82,61 \%$ atau 19 orang siswa tuntas mendeain rumah tanpa harus melakukan remidial, adapun sisanya sebanyak $17,39 \%$ atau 4 orang baru dinyatakan tuntas setelah remidial. Pada tahap kedua, siswa ditugaskan untuk mempraktekkan materi dengan mendesain denah rumah. Hasil ketercapaian tuntas $100 \%$. Tampilan video pembelajaran desain rumah dalam bentuk Microsoft word dengan memanfaatkan aplikasi bandicam, disajikan pada Gambar 1.

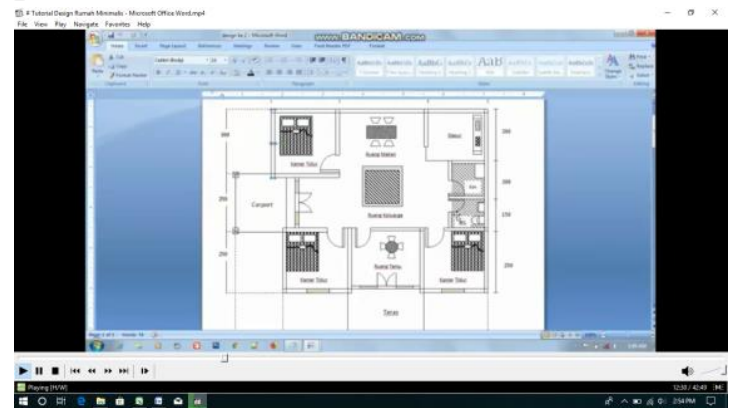

Gambar 1. Video Pembelajaran Desain Rumah dalam Bentuk Microsoft Word Dengan Memanfaatkan Aplikasi Bandicam

Gagne dalam (Pribadi, 2009), menyatakan bahwa pembelajaran sebagai " $a$ set of events embedded in purposeful activities that facilitate learning" (p. 1). Pembelajaran adalah serangkaian aktivitas yang sengaja diciptakan dengan maksud untuk memudahkan terjadinya proses belajar. Menurut (Djamarah \& Zain, 2006), pembelajaran adalah proses yang sengaja dirancang untuk menciptakan terjadinya aktivitas belajar dalam diri individu. Dengan 
kata lain, pembelajaran merupakan sesuatu hal yang bersifat ekternal dan sengaja dirancang untuk mendukung terjadinya proses belajar internal dalam diri individu.

Pembelajaran adalah proses interaksi mahasiswa dengan pendidik dan sumber belajar pada suatu lingkungan belajar. Pembelajaran merupakan bantuan yang diberikan pendidik agar dapat terjadi proses perolehan ilmu dan pengetahuan, penguasaan kemahiran dan tabiat, serta pembentukan sikap dan kepercayaan pada mahasiswa. Dengan kata lain, pembelajaran adalah proses untuk membantu mahasiswa agar dapat belajar dengan baik (Wikipedia, 2013).

Sejalan dengan (Djamarah \& Zain, 2006), menyatakan bahwa tujuan pembelajaran merupakan tujuan intermedier (antara), yang paling langsung dalam kegiatan belajar mengajar di kelas. Tujuan pembelajaran dikenal ada dua, yaitu TIU (Tujuan Intruksional Umum) dan TIK (Tujuan Instruksional Khusus).

Mendesain rumah adalah sebuah gambar yang dibuat atas dasar pengetahuan ilmu teknik yang dapat menunjukkan (menggambarkan) benda-benda yang nantinya akan diwujudkan pada kenyataan di lapangan (Widomoko, 2005).

Pengembangan media pembelajaran berbasis teknologi informasi komunikasi (TIK) misalnya dengan menggunakan media video dalam penyajian materi pembelajaran. Media video atau audio visual adalah media yang mempunyai unsur suara dan unsur gambar. Jenis media ini mempunyai kemampuan yang lebih baik, karena meliputi kedua jenis media yang pertama dan kedua (Djamarah \& Zain, 2006).

Teknologi video memberi keuntungan optimal jika digunakan sesuai dengan potensi yang dikandungnya. Media video memberi kesempatan kepada penggunanya untuk belajar melalui unsur suara (audio) dan gambar (visual) secara simultan. Media ini dapat digunakan untuk menyampaikan informasi dan pengetahuan secara realistik dan konkret, yang tidak mungkin disampaikan oleh media cetak ( (Pribadi, 2009).

Pembelajaran adalah proses yang sengaja dirancang untuk menciptakan terjadinya aktivitas belajar dalam diri individu. Dengan kata lain, pembelajaran merupakan sesuatu hal yang bersifat eksternal dan sengaja dirancang untuk mendukung terjadinya proses belajar internal dalam diri individu (Pribadi, 2009).

Video pembelajaran adalah proses yang sengaja dirancang untuk menciptakan terjadinya aktivitas belajar berbasis teknologi informasi komunikasi (TIK) melalui unsur suara (audio) dan gambar (visual) secara simultan.

Bandicam adalah program terbaik untuk merekam gambar, gim dan kamera web. Bandicam adalah program perekam paling ringan untuk Windows yang bisa merekam apa pun di layar PC-mu dengan kualitas tinggi. Serta bisa merekam di area tertentu di layar PC-mu, atau menangkap gambar yang memakai teknologi DirectX/OpenGL/Vulkan.

Bandicam membantumu merekam gim dengan kompresi tertinggi, serta menjaga kualitas video semirip dengan aslinya, dan memberi performa lebih tinggi dari program lain yang memiliki fitur yang sama (Bandicam, 2019).

Utilitas perekam layar yang dikembangkan oleh perusahaan perangkat lunak Korea Selatan Bandisoft. Selain untuk merekam layar PC dengan ukuran penuh, Bandicam juga bisa digunakan untuk merekam area layar dengan ukuran tertentu. Bandicam banyak digunakan untuk merekam game, video, presentasi, layar komputer dengan kualitas hasil yang sangat baik. Anda dapat memanfaatkan software ini untuk membuat tutorial komputer, pelajaran 
online akademik, demonstrasi dan lain sebagainya (Termasmedia.com, 2019).

Berdasarkan data ketuntasan belajar didapatkan bahwa penerapan media audio visual mampu meningkatkan ketuntasan belajar siswa. Hal yang sama diberikan oleh Herayanti \& Habini (2017) bahwa media berbasis komputer mampu meningkatkan kemampuan berpikir siswa. Terlebih Hermansyah et al. (2017) juga menemukan bahwa media berbasis komputer mampu meningkatkan penguasaan konsep dan kreativitas siswa. Media berbasis komputer memang sangat efektif diterapkan pada pembelajaran berbasis keterampilan karena mendukung kemampuan berpikir, penguasaan konsep dan kreativitas yang dibutuhkan oleh siswa.

\section{PENUTUP}

Pada penelitian ini telah dikembangkan sebuah media audio visual berbasis bandicam. Efektifitas media pembelajaran audio visual sangat baik, hal ini terlihat dari ketuntasan klasikal siswa yang mencapai $100 \%$ pada pertemuan akhir. Bandicam menggabungkan kepraktisan microsoft word dan media audi visual berbentuk video.

\section{REFERENSI}

Arsyad. 2011. Media Pengajaran. Jakarta: Raja Grafindo Persada.

Bandicam. 2019. Bandicam. Retrieved 3 1, 2019, from Bandicam: https://www.bandicam.com/id/

Calhoun, C. C., \& Finch, A. V. 1982. Vocational Education: Concepts and Operation (2nd ed.). Belmont,California: Wadword Publishing Company.

Djamarah, S. B., \& Zain, A. 2006. Strategi Belajar Mengajar. Jakarta: PT. Rineka Cipta.

Herayanti, L., \& Habibi, H. 2017. Model Pembelajaran Berbasis Masalah
Berbantuan Simulasi Komputer untuk Meningkatkan Keterampilan Berpikir Kritis Calon Guru Fisika. Jurnal Pendidikan Fisika dan Teknologi, 1(1), 61-66.

Hermansyah, H., Gunawan, G., \& Herayanti, L. 2017. Pengaruh penggunaan laboratorium virtual terhadap penguasaan konsep dan kemampuan berpikir kreatif siswa pada materi getaran dan gelombang. Jurnal Pendidikan Fisika dan Teknologi, 1(2), 97-102.

Pengetahuan, S. 2015. 40 Pengertian Pendidikan Menurut Para Ahli (Pembahasan Lengkap). Retrieved 3 1, 2019, from 40 Pengertian Pendidikan Menurut Para Ahli (Pembahasan Lengkap): http://www.seputarpengetahuan.co.i d/2015/2015-pengertian-pendidikanmenurut-para-ahli.html

Pribadi, B. A. 2009. Model Desain Sistem Pembelajaran . Jakarta: PT. Dian Rakyat.

Rini, Y. S., \& Tari, J. P. S. (2013). Pendidikan: Hakekat, Tujuan, dan Proses.UNY Press: Yogyakarta.

Termasmedia.com. 2019. Bandicam. Retrieved 3 1, 2019, from Bandicam: https://www.termasmedia.com/lainn ya/sofware/689-bandicam-ofwareterbaik-untuk-hasil-rekan-layarberkualitas.htmlBandicam,Sofware Terbaik Untuk Hasil Rekam layar Berkualitas

Widomoko. 2005. Kontruksi Bangunan Gedung Satu Lantai. Malang: Universitas Negeri Malang.

Wikipedia. 2013. Pembelajaran. Retrieved 12 12, 2013, from Pembelajaran: http://id.wikipedia.org/wiki/Pembela jaran,html. 